Article

\title{
Can Digital Inclusive Finance Impact on the Rural Income? An Empirical Study in Henan Province, China
}

\author{
Xiuhui Li, Zihan Zhang and Fan Yang*
}

School of economics and management, Zhejiang Ocean University, Zhoushan 316022, Zhejiang Province, China;
xiuhui163@126.com (X.L.); 751074623@qq.com (Z.Z.); yang-fan@zjou.edu.cn (F.Y.)
* Correspondence: yang-fan@zjou.edu.cn

\begin{abstract}
This paper empirically analyzes the relationship between digital inclusive finance and rural income, and demonstrates that digital inclusive finance plays a significant role in promoting rural income, based on the 2012-2018 panel data of 17 cities in Henan Province of China. Further dimensional research unveils that all of its breadth of coverage, depth of use and degree of digitization present significant positive correlation with rural income, and a robustness test was conducted through the sub-sample method. In addition, according to regression analysis on the influencing factors of digital inclusive finance through the Tobit model, the level of economic development, the Internet popularity rate and the urbanization rate have a positive effect on the development of digital inclusive finance in Henan, while the income gap between urban and rural areas and the degree of opening up have a negative effect. Finally, predicated on the analysis of the restrictive factors of Henan's digital inclusive finance in increasing rural income, the paper puts forward specific policy proposals based on the native state quo.
\end{abstract}

Keywords: digital inclusive finance; rural income; Henan Province, China; empirical analysis; countermeasures and suggestions

\section{Introduction}

Digital Inclusive Finance (DIF), which was first proposed at the 2016 Hangzhou G20 Summit, refers to all actions of promoting inclusive finance through digital financial services. The products and services of digital inclusive finance, including credit, investment, payment, wealth management and insurance, rely on modern digital technologies for transactions. Digital inclusive finance adopts diverse service methods to ensure the sustainable development of inclusive finance. Characterized by inclusiveness, it improves the financial availability for the poor, eradicates the shortcomings of limited supply of traditional finance, and provides comprehensive financial services for rural low-income and socially vulnerable groups in a prompt and effective manner. With economic growth and the optimization of income distribution and financial services, low-income people can increase their access to funds through inclusive finance, thereby getting rid of poverty to a certain extent [1]. In the meanwhile, the inclusive financial system promotes the inclusive development of finance, consolidates financial stability, and incorporates the low-income into the financial system, thus boosts the reduction of income inequality [2]. The measurement indexes and evaluation system of inclusive finance levels are gradually enriched and perfected, and inclusive finance indexes have been established from three dimensions, such as the product availability, coverage area and utilization degree [3]. There are discrepancies in the effects of poverty alleviation in different dimensions, so it is necessary to do adjustment in accordance with local conditions and to conduct more detailed and deeper research on inclusive finance. Inclusive finance is able to effectively ease the uneven distribution of income [4]. In terms of some countries in Asia, Africa and Latin 
America, it can maximize finance availability and improve service capacity, so that lowand middle-income people can enjoy financial services and narrow the gap of wealth [5]. Moreover, inclusive finance presents its characteristics of inclusive in aspect of eliminating misallocation of traditional financial resources, and also acts a significant role in stimulating employment [6], while alleviating credit constraints and enhancing the technological innovation capabilities of enterprises [7], so as to heighten residents' income.

Digital inclusive finance pays more attention to the utilization of digital technologies such as computers, the Internet and other electronic devices, aiming at improving the availability and utilization rates of financial products and services, but its essence is still inclusive finance [8]. The in-depth application of digital technologies has promoted the innovation of inclusive finance. The construction of a complete digital financial inclusive system should be considered from three perspectives such as financial consumers, market regulators and suppliers [9]. Digital inclusive finance applies modern information technologies to alleviate the limitations of traditional financial services in time and space, improve financial service capabilities, and effectively decrease the operating time and capital costs of financial institutions [10]. The development of digital inclusive finance is conducive to solving the "inclusive finance paradox". At present, most progress of inclusive finance in China is reflected in digitalization [11]. The success of M-PESA mobile payment in Kenya shows that obtaining financial services by mobile device benefits poverty alleviation [12]. Digital finance is conducive to increasing the breadth of coverage and depth of use of financial services, and mobile financial transactions can lower the time cost of transactions and transportation, thus alleviating poverty [13]. Digital finance can drive GDP growth, provide loans to more companies and individuals short of credit channels, reduce the financial availability of the female, and optimize economic prospects [14]. In terms of the role of digital finance on inclusive finance and financial stability, digital finance can facilitate emerging and developed economies and reduce the cost of obtaining financial services from formal banking institutions for the low-income [15]. Additionally, it can significantly promote household consumption, especially for families with fewer assets, lower incomes, poor financial status, and residents living in third- and fourth-tier cities. The impact of digital finance on household consumption is mainly based on alleviating liquidity constraints, promoting payments and transactions, broadening investment channels, increasing income and strengthening security, which fully reflects the inclusiveness of digital finance [16].Also, development of digital inclusive finance plays a key role in promoting the entrepreneurship of rural residents in the central inland region [17].Meanwhile, the breadth of coverage and depth of use of digital inclusive finance have greatly eased the financial constraints to small and medium-sized enterprises [18], which is beneficial to the development of small and medium-sized enterprises founded by farmers and increase rural income. Digital inclusive finance plays a positive role in the improvement of rural income [19], and it takes more effect in narrowing the urban-rural income gap [20]. Furthermore, as an opportunity to promote the upgrading of the rural industrial structure of China, digital inclusive finance is able to increase the employment opportunities of rural people and drive the increase of rural income [21].

The rapid development of digital inclusive finance has uprooted the inclusive finance's drawbacks of limited coverage and weak sustainability in the market, thereby boosting the rise of rural income. Domestically, the province with the most rural people is Henan, whose agricultural population also takes the largest proportion than others. Therefore, it is of great practical significance to study the impact of Henan's digital inclusive finance on rural income. Based on previous studies, we selected panel data of 17 cities in Henan from 2012 to 2018 to establish a panel regression model for empirical testing and analyzed the impact of digital inclusive finance of Henan on its rural income, based on which we discovered the problems of digital inclusive finance there and put forward countermeasures and suggestions. Figure 1 provides the technology roadmap of the research, which can enrich the theoretical content of the effect of digital inclusive finance and provide decision-making reference for raising rural income in Henan, China. 


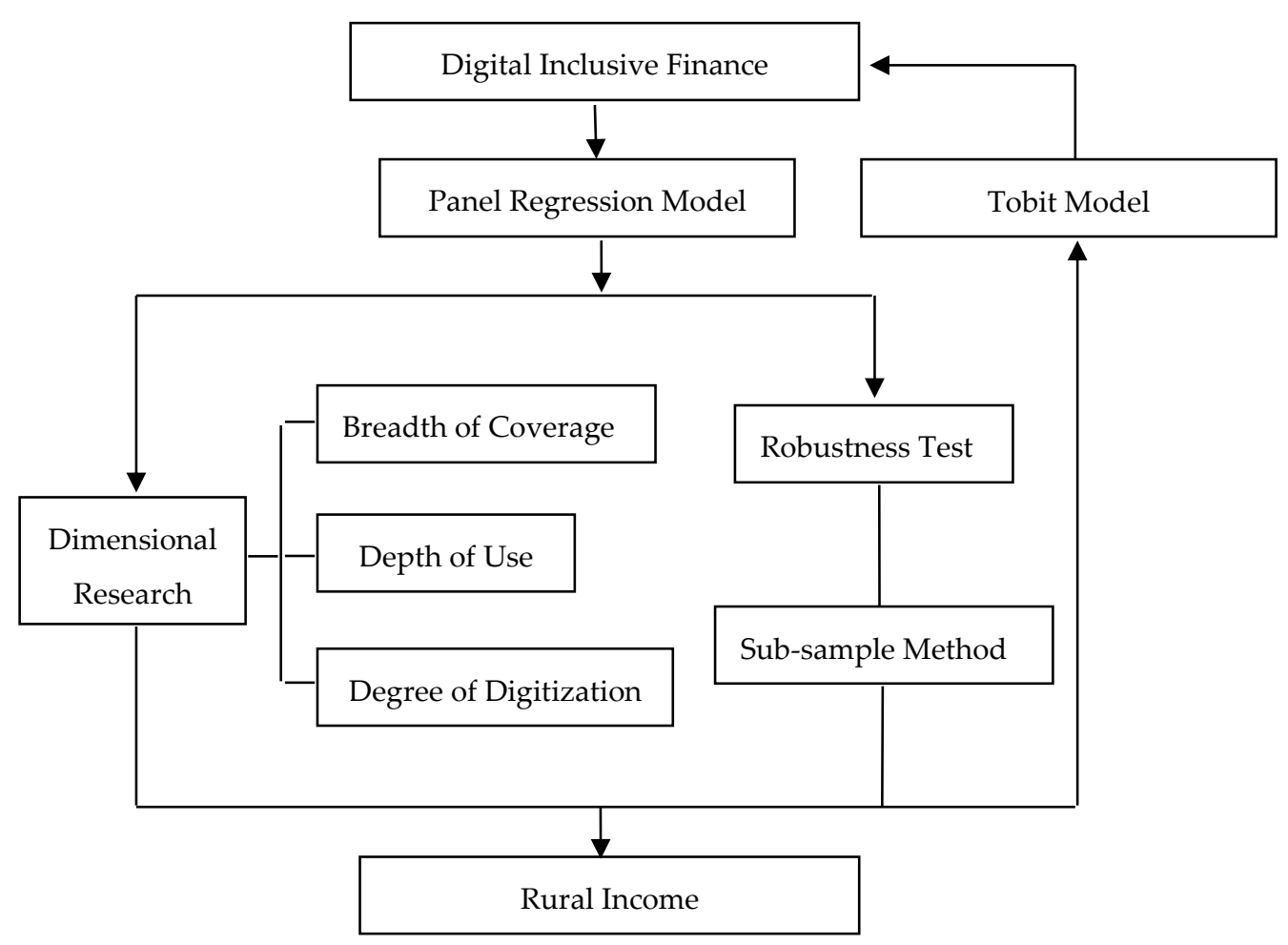

Figure 1. The Technology Roadmap of the Research

\section{Materials and Methods}

\subsection{Index System}

In the paper, the panel data of 17 prefecture-level cities in Henan were selected; rural income was taken as an explained variable; the level of digital inclusive finance was taken as an explanatory variable of the model; other indexes possibly affecting rural income were taken as control variables. The data of the explained and control variables were derived from the "Henan Statistical Yearbook" and Wind database. The variable names, representative symbols and variable descriptions are shown in Table 1.

Table 1. Test Index of the Impact of Digital Inclusive Finance on Rural Income in Henan Province

\begin{tabular}{|c|c|c|c|}
\hline & Variable Name & Symbol & Variable Description \\
\hline $\begin{array}{l}\text { Explained } \\
\text { variable }\end{array}$ & $\begin{array}{l}\text { Level of rural in- } \\
\text { come }\end{array}$ & income & $\begin{array}{l}\text { Per capita disposable income of rural resi- } \\
\text { dents }\end{array}$ \\
\hline \multirow[t]{2}{*}{$\begin{array}{l}\text { Explanatory } \\
\text { variable }\end{array}$} & $\begin{array}{c}\text { Development level } \\
\text { of digital inclusive } \\
\text { finance }\end{array}$ & difi & Digital inclusive finance index \\
\hline & $\begin{array}{l}\text { Industrial struc- } \\
\text { ture }\end{array}$ & is & $\begin{array}{l}\text { Added value of the secondary and tertiary } \\
\text { industries/GDP }\end{array}$ \\
\hline \multirow[t]{2}{*}{$\begin{array}{l}\text { Control } \\
\text { variables }\end{array}$} & $\begin{array}{l}\text { Education ex- } \\
\text { penditure }\end{array}$ & edu & $\begin{array}{l}\text { Regional financial education expendi- } \\
\text { ture/fiscal expenditure }\end{array}$ \\
\hline & $\begin{array}{l}\text { Policies for sup- } \\
\text { porting agriculture }\end{array}$ & poli & $\begin{array}{l}\text { Regional expenditure on agriculture, for- } \\
\text { estry and water affairs/fiscal expenditure }\end{array}$ \\
\hline
\end{tabular}




\begin{tabular}{llr}
$\begin{array}{c}\text { Government ac- } \\
\text { tions }\end{array}$ & gov & Regional fiscal expenditure/GDP \\
$\begin{array}{c}\text { Regional credit } \\
\text { constraints }\end{array}$ & loan & $\begin{array}{c}\text { The balance of CNY loans of financial in- } \\
\text { stitutions at the end of a year/GDP }\end{array}$ \\
\hline
\end{tabular}

\subsubsection{Explained Variable}

Level of rural income (income). The rural per capita income from 2012 to 2014 was represented by the per capita net income of rural households in the "Henan Statistical Yearbook", and the per capita rural income from 2015 to 2018 is represented by the per capita disposable income of rural households [22]. In 2015, the Henan Provincial Bureau of Statistics standardized the index of "rural per capita net income" into "rural per capita disposable income" in accordance with "urban per capita disposable income". It was found by looking up relevant data that they have no big difference. Both of them equal to the sum of wage income, transfer income, property income and operating income [23]. The logarithm of rural income data was taken under the premise of remaining the relationship between the original variables in order to reduce heteroscedasticity and ensure the stability of the data.

\subsubsection{Explanatory Variable}

Development level of digital inclusive finance (difi). The data of 17 cities in Henan in the "Peking University Digital Inclusive Finance Index (2011-2018)" were adopted, and the time spanned from 2012 to 2018. The values were divided by 100 to adjust them to variables based on 1 before regression analysis. In addition, a digital inclusive finance coverage breadth index (cb), a utilization degree index (ud), and an index of digital support service level (dl) were selected as explanatory variables.

\subsubsection{Control Variables}

With reference to the research from related literature, the following five variables were selected as the control variables that affect the level of rural income.

Numbered lists can be added as follows:

1. Industrial structure (is). Alteration of industrial structure may affect labor transfer and resource flow, thereby impacting rural productivity and economic growth. In this paper, the industrial structure index was measured by the proportion of the added value of secondary and tertiary industries in local GDP [24].

2. Education expenditure (edu). The higher educational level of farmers is conducive to cultivating their financial literacy and also diversifying their financial demand. In this paper, the educational part of fiscal expenditure was used to measure the regional educational level [25].

3. Policies for supporting agriculture (poli). The policy reflects how much the government pays attention to rural development. The government's financial support for agriculture is embodied in fiscal expenditure. In the paper, the fiscal expenditure to support agriculture, namely the proportion of expenditure on agriculture, forestry and water conservancy in budgetary expenditure, was used to measure the policies for supporting agriculture [26].

4. Government actions (gov). The tendency of government's fiscal expenditure to cities may widen the gap between urban and rural income, which is not conducive to the increase of rural income. In this paper, the proportion of government's annual fiscal expenditures in GDP was used to measure government actions [27].

5. Regional credit constraints (loan). For a region with the higher level of financial development, its orderly competitive financial organization system is beneficial to satisfying the diverse financial demand of the residents. In this paper, the year-end percentage of the balance of financial institutions' CNY loans in the local GDP was used to express the regional credit constraints [28]. 


\subsection{Descriptive Statistics}

It can be seen from the results in Table 2 that there are differences in the levels of rural income in different regions. The average value of the variables was 9.299, the maximum was 9.983, and the minimum was 8.732. At the same time, the maximum value of digital inclusive finance was 2.7283 , the minimum was only 0.6375 , and the average was 1.6438 , indicating significant differences in regional development. The control variables such as industrial structure, education expenditure, policies for supporting agriculture and regional credit constraints also differed among regions.

Table 2. Descriptive Statistics

\begin{tabular}{cccccc}
\hline variable & $\mathrm{N}$ & $\min$ & $\max$ & mean & $\mathrm{sd}$ \\
\hline income & 119 & 8.732 & 9.983 & 9.299 & 0.256 \\
difi & 119 & 0.637 & 2.728 & 1.644 & 0.520 \\
is & 119 & 0.730 & 0.986 & 0.873 & 0.0640 \\
edu & 119 & 0.116 & 0.271 & 0.200 & 0.0290 \\
poli & 119 & 0.0420 & 0.184 & 0.124 & 0.0270 \\
gov & 119 & 0.104 & 0.231 & 0.159 & 0.0330 \\
loan & 119 & 0.307 & 2.090 & 0.648 & 0.301 \\
\hline
\end{tabular}

\subsection{Related Coefficients of Main Variables}

Data relevance, namely whether there is a problem of multiple collinearity, should be taken into account. As shown in Table 3, the maximum absolute value of the correlation coefficients between the explanatory variable and the control variables is 0.745 , which is less than 0.8 , and most of the coefficients are not very large, so the correlation between the data is not considered to be strong preliminarily. The variance inflation factor (VIF) represents the ratio of the variance between variables with and without multicollinearity. The larger the VIF is, the stronger the collinearity will be. If the explanatory variables are highly correlated, the model may be distorted. According to relevant literature, generally speaking, when $0<\mathrm{VIF}<10$, it is considered that there is no multicollinearity; when $10 \leqq$ $\mathrm{VIF}<100$, it means that there is strong multicollinearity. The maximum value of VIF in this paper was 7.04 , less than 10 , indicating no multicollinearity.

Table 3. Related Coefficients of Main Variables

\begin{tabular}{lllllll}
\hline & difi & is & edu & poli & gov & loan \\
difi & 1 & & & & & \\
\hline is & $0.403^{* * *}$ & 1 & & & & \\
edu & $-0.611^{* * *}$ & $-0.576^{* * *}$ & 1 & & & \\
poli & $-0.162^{*}$ & $-0.685^{* * *}$ & $0.626^{* * *}$ & 1 & $0.516^{* * *}$ & 1 \\
gov & 0.0800 & $-0.745^{* * *}$ & 0.138 & $-0.611^{* * *}$ & -0.00800 & 1 \\
\hline loan & $0.412^{* * *}$ & $0.449^{* * *}$ & $-0.653^{* * *}$ & & & \\
\hline
\end{tabular}

\subsection{Model Construction}

A model (1) was constructed with reference to the existing literature in order to analyze the impact of digital inclusive finance on rural income.

$$
\text { income }_{i, t}=\beta_{0}++\beta_{1} \text { difi }_{i, t}+\beta_{2} i s_{i, t}+\beta_{3} e d u_{i, t}+\beta_{4} \text { poli }_{i, t}+\beta_{5} \text { gov }_{i, t}+\beta_{6} \text { loan }_{i, t}+\varepsilon_{i, t}
$$


At the same time, difi lagged one period, and a regression model (2) was established:

$$
\text { income }_{i, t}=\beta_{0}+\beta_{1} \text { difi }_{i, t-1}+\beta_{2} i s_{i, t}+\beta_{3} e d u_{i, t}+\beta_{4} \text { poli }_{i, t}+\beta_{5} \text { gov }_{i, t}+\beta_{6} \text { loan }_{i, t}+\varepsilon_{i, t}
$$

Among them, income, difi, is, edu, poli, gov and loan represented the levels of rural income, the development level of digital inclusive finance, industrial structure, education expenditure, policies for supporting agriculture, government actions and regional credit constraints. $\beta_{1}, \beta_{2}, \beta_{3}, \beta_{4}, \beta_{5}$ and $\beta_{6}$ represented the estimated parameters corresponding to the variables respectively. ${ }^{\beta_{0}}$ represented the intercept term; $\varepsilon_{\text {represented }}$ the random interference term; i represented the prefecture-level cities in Henan; $t$ represented the time.

Further, the impact on rural income in Henan was analyzed through the three dimensions of the breadth of coverage, depth of use and digitalization degree of digital inclusive finance, thereby establishing following three models, namely (3), (4) and (5):

$$
\begin{aligned}
& \text { income }_{i, t}=\beta_{0}+\beta_{1} c_{i, t}+\beta_{2} i s_{i, t}+\beta_{3} e d u_{i, t}+\beta_{4} \text { poli }_{i, t}+\beta_{5} \text { gov }_{i, t}+\beta_{6} \operatorname{loan}_{i, t}+\varepsilon_{i, t} \text { (3) } \\
& \text { income }_{i, t}=\beta_{0}+\beta_{1} u d_{i, t}+\beta_{2} i_{i, t}+\beta_{3} e d u_{i, t}+\beta_{4} \text { poli }_{i, t}+\beta_{5} \text { gov }_{i, t}+\beta_{6} \text { loan }_{i, t}+\varepsilon_{i, t}(4) \\
& \text { income }_{i, t}=\beta_{0}+\beta_{1} d l_{i, t}+\beta_{2} i s_{i, t}+\beta_{3} e d u_{i, t}+\beta_{4} \text { poli }_{i, t}+\beta_{5} \text { gov }_{i, t}+\beta_{6} \text { loan }_{i, t}+\varepsilon_{i, t}
\end{aligned}
$$

Among them, cb, ud and $\mathrm{dl}$ represented the breadth of coverage, depth of use, and degree of digital support services of digital inclusive finance. Others were the same as above.

\section{Results and Analysis}

\subsection{Empirical analysis on the impact of digital inclusive finance on rural income}

There are three analysis models for panel data, including mixed effect model, fixed effect model, and random effect model [29]. Based on the basic principles of economics, the paper holds that it is more appropriate to select a fixed effect model to research the impact of digital inclusive finance on rural income. In the meanwhile, the $\mathrm{P}$ value in the $\mathrm{F}$ test was 0.0000 , and the null hypothesis was rejected at the $1 \%$ level, so the fixed effect model was selected in comparison with the mixed effect model. In addition, the P value in the LM test was 0.0000 , and the null hypothesis was significantly rejected at the $1 \%$ level, so the random effect model was selected in comparison with the mixed effect model. Finally, the P value in the Hausmann test was 0.0131 , and the null hypothesis was rejected at the $5 \%$ level, so the fixed effect model was selected for analysis. Measurement software stata16.0 was applied to investigate the regression analysis results of the three models in order to prevent model setting errors. The random effect and OLS analysis were only for reference, as shown in Table 4.

Table 4. Empirical Results of the Impact of Digital Inclusive Finance on Farmers' Income

\begin{tabular}{cccc|ccc}
\hline & \multicolumn{3}{c|}{$(\mathbf{1})$} & \multicolumn{3}{c}{ (2) } \\
\hline VARIA- & OLS & FE & RE & OLS & FE & RE \\
BLES & & & & & & \\
income & income & income & & & \\
\hline difi & $0.360^{* * *}$ & $0.348^{* * *}$ & $0.330^{* * *}$ & & & \\
& $(14.98)$ & $(33.01)$ & $(27.41)$ & & & \\
difi (-1) & & & & $0.329^{* * *}$ & $0.301^{* * *}$ & $0.281^{* * *}$ \\
& & & & $(11.71)$ & $(27.11)$ & $(21.48)$ \\
is & 0.214 & 0.293 & $0.746^{* * *}$ & 0.168 & 0.234 & $0.726^{* * *}$
\end{tabular}




\begin{tabular}{cccc|ccc} 
& $(0.81)$ & $(1.60)$ & $(2.88)$ & $(0.57)$ & $(1.23)$ & $(2.71)$ \\
edu & -0.380 & $-0.326^{* *}$ & $-0.353^{* * *}$ & -0.364 & $-0.556^{* * *}$ & $-0.629^{* * *}$ \\
& $(-0.94)$ & $(-2.87)$ & $(-2.70)$ & $(-0.82)$ & $(-6.13)$ & $(-7.11)$ \\
poli & $-1.151^{* *}$ & 0.139 & -0.007 & $-1.092^{* *}$ & 0.263 & 0.148 \\
& $(-2.52)$ & $(0.58)$ & $(-0.03)$ & $(-2.18)$ & $(1.11)$ & $(0.64)$ \\
gov & $-1.992^{* * *}$ & $0.756^{* * *}$ & 0.058 & $-2.161^{* * *}$ & $0.669^{* * *}$ & 0.054 \\
& $(-4.31)$ & $(3.02)$ & $(0.21)$ & $(-4.41)$ & $(3.31)$ & $(0.29)$ \\
loan & $0.119^{* * *}$ & -0.043 & 0.037 & $0.131^{* * *}$ & 0.003 & $0.085^{*}$ \\
& $(3.79)$ & $(-0.78)$ & $(0.91)$ & $(3.91)$ & $(0.04)$ & $(1.94)$ \\
Constant & $8.977^{* * *}$ & $8.427^{* * *}$ & $8.142^{* * *}$ & $9.163^{* * *}$ & $8.650^{* * *}$ & $8.321^{* * *}$ \\
& $(30.45)$ & $(58.63)$ & $(43.61)$ & $(28.77)$ & $(58.90)$ & $(42.88)$ \\
\hline Observa- & 119 & 119 & 119 & 102 & 102 & 102 \\
tions & & & & & & \\
\hline R-squared & 0.904 & 0.988 & 0.988 & 0.8885 & 0.9901 & 0.9891 \\
\hline
\end{tabular}

Table 4 (1) indicates that according to the analysis of the three models, the development level of digital inclusive finance in Henan and the level of rural income presented significant positive correlation at the level of $1 \%$, indicating that the development of digital inclusive finance can increase rural per capita income. The model fit degree in fixed effect analysis was 0.988 , presenting a better degree of fitting. The coefficient of difi was 0.348 , demonstrating that in the case that other control variable remains constant, rural income will increase by $0.348 \%$ as the development level of digital inclusive finance rises by one unit. It can be seen that digital inclusive finance is beneficial to heightening rural income, which is consistent with the theoretical analysis above. In the case that difi lagged by one period, the regression results were still significant, indicating that digital inclusive finance is featured by continuity. The development of digital inclusive finance in the last period can positively affect the current rural income, the relation of which is clearly testified and shown in Figure 2.

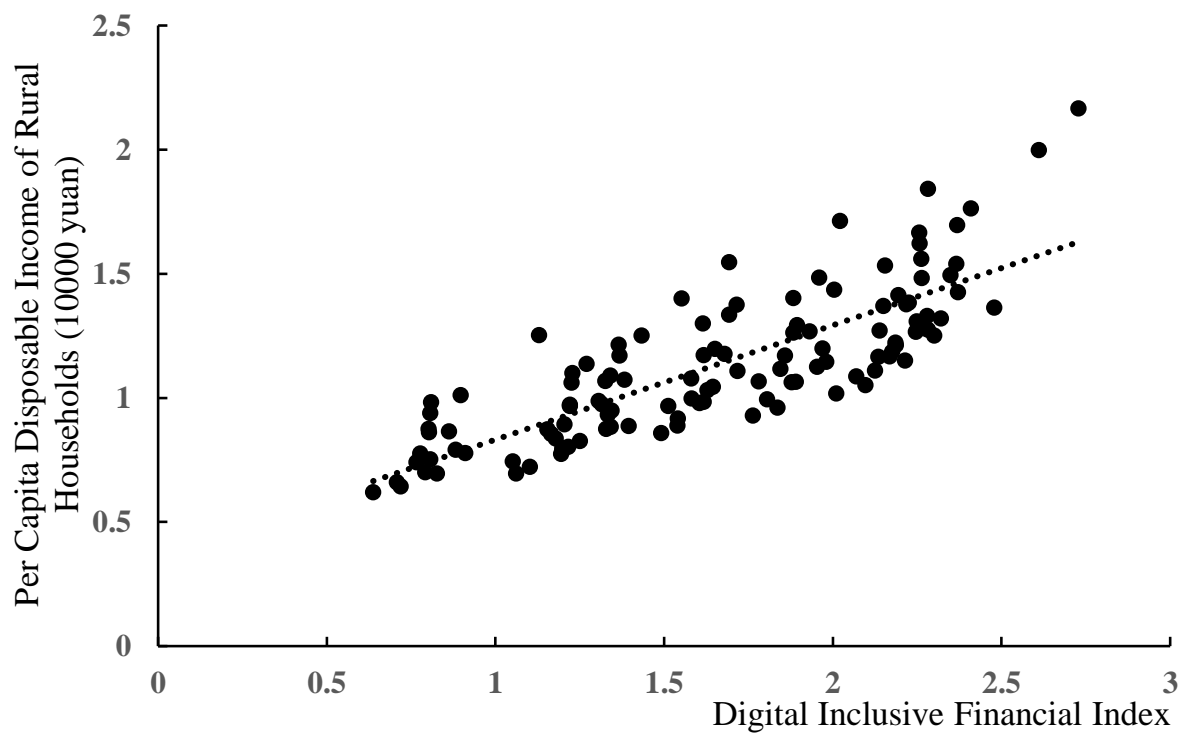

Figure 2. The Relation between Digital Inclusive Financial Index and Per Capita Disposable Income of Rural Households

From the perspective of the control variables, the coefficient of industrial structure was positive but not significant, the possible reason of which was that the primary 
industry was the main source of rural income, and farmers obtained few job opportunities in on-agricultural industries. The coefficient of education expenditure was negative and significantly corrected with rural income, the possible reason of which was that the government's education expenditure was unreasonable, or that the well-educated farmers decided to stay in cities, which resulted in the destitute of high-quality talents in rural areas, thereby hindering the increase of rural economy. Policies for supporting agriculture were not significantly correlated with the level of rural income, but its coefficient was positive. It might be because that the expenditure on agriculture, forestry and water conservancy in the local public budget was invested into the primary industry, which brought impact on the income of rural residents, but the social economy development and the enhanced economic advantages of secondary and tertiary industries could debilitate the impact. Government actions and rural income had significant positive correlation, indicating that government fiscal expenditure helped to increase rural income as a whole, and could play a more remarkable role by further optimizing expenditure on education as well as agricultural, forestry and water conservancy. Regional credit constraints were not significantly correlated with rural income, which might be because that relatively closed financial markets and the high thresholds of traditional financial institutions often exclude farmers from financial services, thereby increasing difficulties to fulfill their credit demand and impeding the rise of rural income.

\subsection{Empirical analysis of Multi-Dimensions}

In the three dimensions of the "digital inclusive finance system", the breadth of coverage is a prerequisite; the depth of use represents actual usage; the degree of digitization can be regarded as a potential condition. Among them, the breadth of coverage index took the largest weight of $54.0 \%$; the depth of use index occupied $29.7 \%$, and the digital degree index occupied $16.3 \%$. The impact of digital inclusive finance in Henan on rural income was considered from these three perspectives, and the results of regression using the fixed effect model are shown in Table 5. The fitting degrees of models (1), (2) and (3) are so good that they were greater than 0.93 , presenting better performance. The breadth of coverage variable of digital inclusive finance in Henan was highly correlated with the rural income at the level of $1 \%$, indicating that the increasing breadth of financial coverage can drive the growth of rural income. The depth of use had significant positive correlation with the rural income at the level of $1 \%$, indicating that the deepened use of finance will help to alleviate poverty in rural areas and increase rural income. The investigation from these three aspects demonstrated that the level of digital support services for digital inclusive finance in Henan is positively correlated with rural income at a significant level of $1 \%$, that is to say, the higher level of mobilization and digitalization is conducive to alleviating poverty and increasing rural income. It is consistent with the empirical analysis above.

Table 5. Empirical Results of the Impact of the Sub-dimensions of Digital Inclusive Finance on Farmers' Income

\begin{tabular}{clll}
\hline & $\begin{array}{l}\text { (1) } \\
\text { income }\end{array}$ & $\begin{array}{l}\text { (2) } \\
\text { income }\end{array}$ & $\begin{array}{l}\text { (3) } \\
\text { income }\end{array}$ \\
\hline $\mathrm{cb}$ & $\begin{array}{l}0.380^{* * *} \\
(32.61)\end{array}$ & & \\
& & $0.185^{* * *}$ & \\
$\mathrm{ud}$ & $(8.17)$ & \\
& & & $0.187^{* * *}$ \\
$\mathrm{dl}$ & & $12.53)$ \\
& & $1.620^{*}$ & $2.843^{* * *}$
\end{tabular}




\begin{tabular}{llll} 
& $(1.63)$ & $(2.10)$ & $(5.04)$ \\
edu & -0.0214 & $-1.820^{* * *}$ & 0.0327 \\
& $(-0.16)$ & $(-4.84)$ & $(0.11)$ \\
poli & 0.216 & 0.376 & 0.0262 \\
& $(0.95)$ & $(0.73)$ & $(0.05)$ \\
gov & $0.728^{* *}$ & 0.779 & 0.407 \\
& $(2.20)$ & $(0.91)$ & $(0.33)$ \\
loan & -0.0395 & 0.306 & $0.262^{*}$ \\
& $(-0.96)$ & $(1.59)$ & $(1.75)$ \\
\multirow{2}{*}{ _cons } & $8.245^{* * *}$ & $7.587^{* * *}$ & $6.175^{* * *}$ \\
& $(38.38)$ & $(13.29)$ & $(15.35)$ \\
\hline N & 119 & 119 & 119 \\
\hline R-squared & 0.9916 & 0.9323 & 0.9481 \\
\hline
\end{tabular}

\subsection{Robustness Test}

Based on the existing research, a random sample method was selected for testing, so as to verify the reliability of the result that digital inclusive finance is beneficial to improving rural income.

$80 \%$ of the samples were randomly selected from the original ones, and regression analysis on the sub-samples was carried out through the panel data fixed effect model. The empirical results are shown in Table 6. A method of increasing the control variables one by one was adopted for (2)-(6), and the development level of digital inclusive finance, in this process, always maintained a significant positive correlation with the level of rural income, which shows that the analysis results are significantly effective, and digital inclusive finance can increase rural income.

Table 6. Robustness Test Results of Sub-samples

\begin{tabular}{|c|c|c|c|c|c|c|}
\hline & $\begin{array}{c}\text { (1) } \\
\text { income }\end{array}$ & $\begin{array}{c}(2) \\
\text { income }\end{array}$ & $\begin{array}{c}\text { (3) } \\
\text { income }\end{array}$ & $\begin{array}{c}(4) \\
\text { income }\end{array}$ & $\begin{array}{c}\text { (5) } \\
\text { income }\end{array}$ & $\begin{array}{c}\text { (6) } \\
\text { income }\end{array}$ \\
\hline Difi & $\begin{array}{c}0.373^{* * *} \\
(53.92)\end{array}$ & $\begin{array}{c}0.357^{* * *} \\
(29.78)\end{array}$ & $\begin{array}{c}0.348^{* * *} \\
(29.85)\end{array}$ & $\begin{array}{c}0.349^{* * *} \\
(32.11)\end{array}$ & $\begin{array}{c}0.343^{* * *} \\
(31.91)\end{array}$ & $\begin{array}{c}0.351^{* * * *} \\
(28.44)\end{array}$ \\
\hline Is & & $\begin{array}{c}0.507^{* *} \\
(2.22)\end{array}$ & $\begin{array}{l}0.451^{*} \\
(1.76)\end{array}$ & $\begin{array}{l}0.375 \\
(1.43)\end{array}$ & $\begin{array}{l}0.394 \\
(1.50)\end{array}$ & $\begin{array}{l}0.321 \\
(1.49)\end{array}$ \\
\hline Edu & & & $\begin{array}{c}-0.384^{* *} \\
(-2.55)\end{array}$ & $\begin{array}{c}-0.436^{* *} \\
(-2.32)\end{array}$ & $\begin{array}{l}-0.301 \\
(-1.53)\end{array}$ & $\begin{array}{l}-0.286 \\
(-1.50)\end{array}$ \\
\hline Poli & & & & $\begin{array}{l}0.238 \\
(0.65)\end{array}$ & $\begin{array}{l}0.196 \\
(0.55)\end{array}$ & $\begin{array}{c}0.0922 \\
(0.27)\end{array}$ \\
\hline Gov & & & & & $\begin{array}{l}0.649 \\
(1.62)\end{array}$ & $\begin{array}{c}0.877^{* *} \\
(2.80)\end{array}$ \\
\hline Loan & & & & & & $\begin{array}{c}-0.0604 \\
(-1.16)\end{array}$ \\
\hline _cons & $\begin{array}{l}8.689^{* * *} \\
(752.56)\end{array}$ & $\begin{array}{c}8.272^{* * *} \\
(45.34)\end{array}$ & $\begin{array}{c}8.411^{* * *} \\
(37.00)\end{array}$ & $\begin{array}{c}8.457^{* * *} \\
(38.48)\end{array}$ & $\begin{array}{c}8.327^{* * *} \\
(38.98)\end{array}$ & $\begin{array}{c}8.390^{* * *} \\
(43.47)\end{array}$ \\
\hline
\end{tabular}




\begin{tabular}{ccccccc}
\hline $\mathrm{N}$ & 95 & 95 & 95 & 95 & 95 & 95 \\
\hline R-squared & 0.985 & 0.986 & 0.986 & 0.986 & 0.987 & 0.987 \\
\hline
\end{tabular}

Furthermore, a robustness test was carried out for the impact of digital inclusive finance on the income of rural residents in different dimensions. The results are shown in Table 7. In the three dimensions of the breadth of coverage, depth of use and digitalization degree, digital inclusive finance has significant positive correlation with rural income at the level of $1 \%$, which is consistent with the above results.

Table 7. Robustness Test Results in Different Dimensions

\begin{tabular}{|c|c|c|c|}
\hline & $\begin{array}{c}\text { (1) } \\
\text { income }\end{array}$ & $\begin{array}{c}(2) \\
\text { income }\end{array}$ & $\begin{array}{c}\text { (3) } \\
\text { income }\end{array}$ \\
\hline $\mathrm{cb}$ & $\begin{array}{c}0.386^{* * *} \\
(36.65)\end{array}$ & & \\
\hline $\mathrm{ud}$ & & $\begin{array}{c}0.184^{* * *} \\
(7.21)\end{array}$ & \\
\hline $\mathrm{dl}$ & & & $\begin{array}{c}0.194^{* * *} \\
(12.69)\end{array}$ \\
\hline is & $\begin{array}{l}0.270 \\
(1.09)\end{array}$ & $\begin{array}{l}1.654^{*} \\
(1.82)\end{array}$ & $\begin{array}{c}2.753^{* * *} \\
(4.46)\end{array}$ \\
\hline edu & $\begin{array}{l}-0.145 \\
(-0.67)\end{array}$ & $\begin{array}{c}-1.915^{* * *} \\
(-3.72)\end{array}$ & $\begin{array}{l}0.135 \\
(0.31)\end{array}$ \\
\hline poli & $\begin{array}{l}0.405 \\
(1.72)\end{array}$ & $\begin{array}{l}0.275 \\
(0.35)\end{array}$ & $\begin{array}{l}-0.369 \\
(-0.73)\end{array}$ \\
\hline gov & $\begin{array}{l}0.657 \\
(1.69)\end{array}$ & $\begin{array}{l}1.014 \\
(1.03)\end{array}$ & $\begin{array}{l}1.216 \\
(0.99)\end{array}$ \\
\hline loan & $\begin{array}{c}-0.0489 \\
(-1.26)\end{array}$ & $\begin{array}{l}0.258 \\
(1.46)\end{array}$ & $\begin{array}{l}0.193 \\
(1.26)\end{array}$ \\
\hline _cons & $\begin{array}{c}8.379^{* * *} \\
(35.56)\end{array}$ & $\begin{array}{c}7.585^{* * *} \\
(10.68)\end{array}$ & $\begin{array}{c}6.185^{* * *} \\
(13.50)\end{array}$ \\
\hline $\mathrm{N}$ & 95 & 95 & 95 \\
\hline R-squared & 0.9912 & 0.9249 & 0.9463 \\
\hline
\end{tabular}

\section{Tobit Regression Analysis}

The above analysis results show that digital inclusive finance in Henan is conducive to the increase of rural income. Then what are the main factors influencing it in Henan? Stata software was applied to perform Tobit model regression analysis to explore the influencing factors.

In the paper, we selected the data of Henan from 2012 to 2018, took the level of digital inclusive finance as the explanatory variable, and the economic development level, Internet penetration rate, urban-rural income gap, population density, urbanization rate, and degree of opening up as explanatory variables. The data of the explained variables came from the "Peking University Digital Inclusive Finance Index (2011-2018)", and the data of the explanatory variables came from the "Henan Statistical Yearbook" and Wind data base. The variable names, representative symbols, and variable descriptions are shown in Table 8 . The logarithms of the economic development level and population density were 
taken under the premise of remaining the relationship between the original variables in order to reduce heteroscedasticity and ensure the stability of the data.

Table 8. Test Index of the Factors of Impacting Digital Inclusive Finance in Henan Province

\begin{tabular}{|c|c|c|c|}
\hline & Variable name & $\begin{array}{l}\text { Repre- } \\
\text { sentative } \\
\text { symbol }\end{array}$ & Variable description \\
\hline \multirow[t]{3}{*}{$\begin{array}{l}\text { Explained } \\
\text { variable }\end{array}$} & Development level of DIF & difi & Digital inclusive finance index \\
\hline & $\begin{array}{l}\text { Level of economic develop- } \\
\text { ment }\end{array}$ & gdp & Per capita GDP \\
\hline & Internet popularity rate & uni & Number of netizens /total population \\
\hline \multirow[t]{4}{*}{$\begin{array}{c}\text { Explanatory } \\
\text { variables }\end{array}$} & Urban-rural income gap & gap & $\begin{array}{l}\text { Per capita disposable income of urban } \\
\text { residents/ that of rural households }\end{array}$ \\
\hline & Population density & pop & Total population/total area \\
\hline & Urbanization rate & urb & Urban population/total population \\
\hline & Degree of opening up & open & Total import and export/GDP \\
\hline
\end{tabular}

\subsection{Explained Variable}

Digital inclusive finance development level (difi). In the paper, the data of Henan in the "Peking University Digital Inclusive Finance Index (2011-2018)" was adopted, and time spanned from 2012 to 2018. The values were divided by 100 to adjust them to variables based on 1 before regression analysis.

\subsection{Explanatory Variables}

1. The level of economic development (gdp). In areas with fast economic development, financial institutions have the stronger capability of providing financial services, the quicker iteration of digital technologies and the high level of digital inclusive finance [30]. In the paper, per capita GDP was taken as a measurement index.

2. Internet popularity rate (Int). The development of digital inclusive finance is inseparable from the support of Internet infrastructure construction [31].In view of data availability, the Internet popularity rate, namely the proportion of the number of netizens to the total population of a region, was taken as an index.

3. Urban-rural income gap (gap). Excessive urban-rural income gaps stimulate financial institutions to distribute financial services to cities with higher income, which will affect the overall improvement of the digital inclusive finance level [32]. In the paper, the index was expressed by the ratio of the urban to the rural per capita disposable income.

4. Population density (pop). Population density will influence the circulation of financial services and products, which in turn affects the distribution of financial institutions and the financial convenience. Moreover, infrastructure construction tends to be more perfect in areas with high population density [33]. The index was expressed by the ratio of the total population to the total area.

5. Urbanization rate (urb). The higher urbanization level indicates more immigration into cities and more people gaining access to the Internet and other infrastructure and financial services, so that the level of digital inclusive finance will be higher [34]. The index was expressed by the proportion of the urban population to the total in the region. 
6. Degree of opening up (open). The degree of opening up of China remains at a relatively high level, but financial development lingers in its infancy. The incongruous issue will hinder the development of digital inclusive finance rather than boosting it [35]. The index was expressed by the ratio of total import and export to GDP.

\subsection{Tobit Regression Results}

The basic expression of the Tobit model is as follows:

$$
\text { difi }=\alpha+\beta_{1} \ln g d p+\beta_{2} u n i+\beta_{3} g a p+\beta_{4} u r b+\beta_{5} \ln p o p+\beta_{6} \text { open }+\varepsilon_{(6)}
$$

difi, lngdp, Int, gap, urb, lnpop and open represented the development level of digital inclusive finance, economic development level, Internet popularity rate, urban-rural income gap, population density, urbanization rate and degree of opening up, respectively; $\alpha$ represented a constant term, and $\varepsilon$ represented a random interference term.

Table 9. Tobit Regression Results of the Factors Influencing Digital Inclusive Finance

\begin{tabular}{cc}
\hline Variable & Regression coefficient \\
\hline lngdp & $0.043^{* * *}$ \\
Int & $0.105^{* * *}$ \\
gap & $-0.158^{* * *}$ \\
urb & $1.587^{* * *}$ \\
lnpop & -0.849 \\
open & $-0.099^{* * *}$ \\
\hline
\end{tabular}

Note: ${ }^{* * *}$ means significant at the level of $1 \%$.

The regression results in Table 9 show that the factors that promote the development of digital inclusive finance in Henan include the economic development level, Internet popularity rate and urbanization rate. The development of digital inclusive finance is mainly at providing low-income groups access to financial resources and services, and improving their income levels and consumption power, thereby narrowing the welfare gap between urban and rural areas in a country or a region. The construction of public infrastructure has become more and more complete with the improvement of the economic development of Henan. As the supply capacity of digital inclusive financial services keeps on rising, residents' awareness of and demand for digital financial products are bound to increase, which in turn improves the development level of digital inclusive finance in Henan. The Internet offers supports to digital inclusive finance in terms of infrastructure. The increasing number of netizens in Henan reveals that the Internet popularity rate maintains an upward trend, which has greatly upgraded the supply capacity and use efficiency of digital inclusive financial services in Henan. The ascending urbanization level of Henan indicates that an increasing number of people flowing into cities and towns from countryside have more opportunities of learning and using Internet services and financial resources, which helps to raise the development level of digital inclusive finance.

Factors with a negative effect on the level of digital inclusive finance in Henan embrace the urban-rural income gap and the degree of opening up. The widening income gap will lead imbalanced distribution of digital inclusive financial resources between urban and rural areas, while the increasing degree of opening up will drive financial services to flow into areas with developed foreign trade. Both of them could make it difficult for financial services to benefit low-income groups, thus encumbering the improvement of digital inclusive finance level in Henan. Only the factor of population density has no significant impact on the level of digital inclusive finance there. It may be because that as a populous province, Henan has fewer differences in the population density between urban 
and rural areas, which make it difficult for the index to reflect differences in infrastructure construction such as financial services and the Internet, so that it is difficult to influence the development of digital inclusive finance.

\section{Discussion}

\subsection{Finance Problems: Analysis on factors of restricting Henan digital Inclusive finance from increasing rural income}

5.1.1. Construction of digital inclusive finance infrastructure in economic development remains to be strengthened

As the economy of Henan continues to grow, it is important to be aware of the inadequate construction of digital inclusive finance infrastructure, especially the defects in the credit investigation system and the regulatory system. Financial institutions apply the credit reporting system as an evaluation standard when issuing loans, so farmers' difficulty to obtain loans is highly related with the unsound credit system. As shown in Figure 3 , the banks of some areas have archived for low-income farmers and registered the credit of small and micro enterprises, but the credit records of most farmers are null, and most financial institutions have not built an effective data sharing mechanism in their infancy.

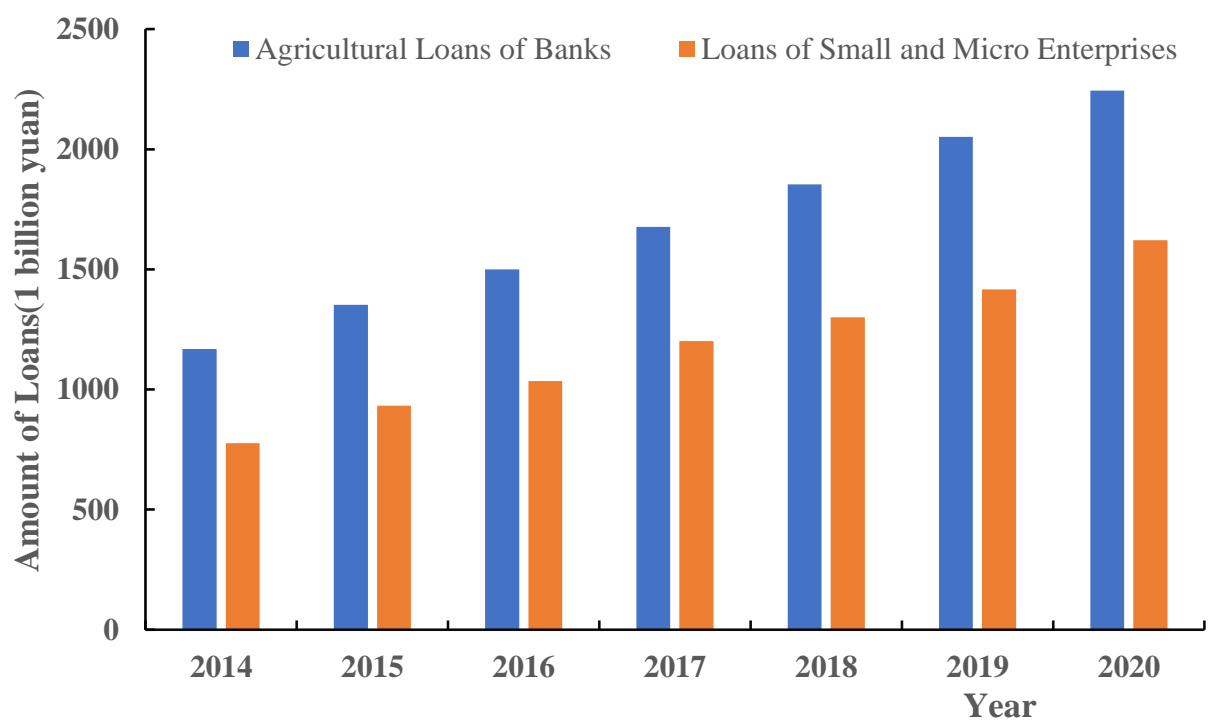

Figure 3. Agricultural Loans of Banks and Loans of Small and Micro Enterprises in Henan Province from 2014 to 2020

Platforms are unable to obtain the real information of farmers and small enterprises when handling their financial services, which debilitates enthusiasm of social credit to support agriculture. Digital inclusive finance relies on the Internet to develop, which brings a certain degree of difficulty to supervision. Hence, the government should pay attention not only to network technology risks, but also to institutional and social risks. First, technical risks mainly include hacker intrusion, virus intrusion and system crash, which will seriously affect the security of customer information, and generate adverse impact on the reputation of financial institutions. Secondly, due to no fixed office locations, traditional market access mechanisms and market entry rules are no longer applicable to most digital inclusive finance platforms. Finally, attention is also worthy of being paid to social risks. One of the advantages of digital inclusive finance is to lower the threshold, which may cause many rural students without paying ability to be involved in credit crises. Once they fail to pay back debt on time, it will jeopardize society.

5.1.2. Construction of the Internet payment system is still incomplete 
Payment services are a key link in the implementation of digital inclusive finance, so it is necessary to speed up the supporting Internet payment system while ensuring the construction of digital inclusive finance infrastructure. Popularity and application of the Internet and smart phones facilitate the penetration of mobile payment services into rural areas. Under the guidance of policies, banks and other financial institutions continuously promote the popularity of mobile payment in the countryside. In spite of the upsurge of mobile payment users in Henan, fewer branches have been deployed by financial institutions due to the remote locations of many rural areas. Villagers can only enjoy financial services in towns, let alone their monotonous business models and small number of POS. Improvement of the mobile payment system requires the support of infrastructure such as the Internet and roads. According to the data of the "Henan Statistical Yearbook 2019", the number of household broadband users in Zhengzhou, the provincial capital of Henan, was $4,120,600$, but Nanyang -- a city with the same number of permanent population -has $1,920,900$ users. It can be seen that the popularity rates of the Internet in Henan have discrepancies in different areas. Thus, Henan should strengthen the construction of Internet infrastructure and improve the level of mobile payment services in rural areas.

5.1.3. Low urbanization makes the supply of digital inclusive finance insufficient in rural areas

The insufficient service supply in rural digital inclusive finance platform in Henan is mainly related to the low level of urbanization. In terms of financial platforms, due to the difficulty of collecting rural credit information, the trouble of managing scatter businesses, the high operating cost of platforms and the less capital demand of the most famers, it is inevitable for the digital inclusive finance platforms to lose motivation of innovating rural services. At the same time, Henan is a large agricultural province characterized by weak agricultural quality, so that its production and operation activities are vulnerable to the natural risks, a kind of force majeure, which is not conducive for farmers to gain credit support from traditional financial institutions. Thus, there are few financial services suitable for rural residents and small enterprises, inadequate innovation in digital inclusive financial service and prominent contradiction between supply and demand. When launching new products, Internet financial platforms are difficult to consider the special demand of consumers, such as interface fonts, voice support and operating habits. Despite the lowering service threshold due to the existence of digital inclusive finance, there are still strict requirements on credit, income and assets of borrowers. Owing to the complex approval procedures of formal banking and financial institutions, farmers who urgently need large amounts of funds prefer P2P online lending platforms with high risks but fast lending.

5.1.4. Urban-rural income gap makes it failed to satisfy the demand for rural digital inclusive finance

Under the influence of the dual economic structure of urban and rural areas, rural low-income groups as well as small enterprises in Henan need financial services to meet their living demand, which differs from the investment and financial management of the rich there. Their financial demand is more urgent. Natural economy on which Henan famers rely to make a living gradually evolves to a large-scale and intensive operating mode like family farm. The famers are striving to become a brand-new agricultural production and operation entity, and their credit demand has gradually transformed from consumer demand to productive investment demand, with the instant change of financial demand's structure. In addition, people at different ages also have discrepancies in demand for inclusive financial products. For example, rural young college students need financial products supporting their entrepreneurship at hometowns; middle-aged farmers favor products of savings more; the elderly expected products targeting at elderly care. Meanwhile, with the advancement of urbanization, informatization and specialization, the credit demand of some rural small enterprises in Henan has switched into large loans from microloans. People in areas with strong industrial development such as Zhengzhou, 
Luoyang, and Xuchang have a greater demand for credit. However, vast majority of digital inclusive finance platforms cannot provide large amounts of capital to enterprises. Hence, there is no doubt that the demand of small enterprises cannot be fulfilled.

\subsection{Policy suggestion for optimizing Henan's digital inclusive finance and increasing rural in- come}

5.2.1. Put more investment in the construction of rural digital inclusive finance infrastructure

The rapid economic development of Henan requires strengthening the construction of rural digital inclusive finance infrastructure, especially the establishment of the credit investigation system and the supervision system. The first is to establish a unified credit data platform for digital inclusive finance. Henan can establish a unified credit investigation standard and integrate the inclusive finance data recorded by various departments. The second is to apply blockchain to the credit investigation system. Blockchain technologies can effectively reduce false credit data, and facilitate storage, query and processing of data. Only by getting approval from all data traders can users obtain information, which avoid illegal attacks. The third is to apply digital technologies to the supervision field. For example, modern information technologies such as big data and cloud computing can be applied to establish a rural customer identification system. A sound management system should focus on precautions while taking into account both halfway control and afterward supervision, avoid the traditional financial supervision mode that pays too much attention to the supply body but underrates consumption, and fully protects the legitimate rights and interests of consumers. The fourth is to ensure the supervision and coordination of various financial departments. At present, some digital inclusive financial platforms in Henan Province basically include a variety of complex businesses such as credit, investment, insurance, and wealth management. Currently, some digital inclusive finance platforms in Henan basically embrace a variety of complex businesses such as credit, investment, insurance and wealth management. In order to ensure normal operation of the industry, financial institutions are required to strictly implement industry standards and practices. The fifth is to establish an efficient appeal platform to resolve disputes of interests, and promptly handle and reply the appeals of rural residents, thereby effectively safeguarding the interests of rural households and other disadvantaged consumer groups.

\subsubsection{Strengthen the construction of the Internet payment system}

A modern Internet payment system is conducive to improving the financial market environment in rural areas, enhancing the convenience of digital inclusive finance services, and increasing rural income in Henan. First of all, it is necessary to strengthen the Internet popularity in Henan, reduce the charging standards for Internet use through subsidies, and increase the number of household broadband users and mobile netizens. The second is to mobilize farmers to use mobile payment platforms. According to the economic foundation of each area, Henan should promulgate a subsidy policy for farmers that is in line with the actual development of local conditions, and let them realize the convenience and efficiency of the mobile payment system through free trials and other methods. The last is to strengthen the promotion of the mobile payment system. Promotion should be carried out during slack seasons, and propaganda staff should target all villagers and ensure that the content is easy to understand.

\subsubsection{Promote the effective supply of rural digital inclusive finance through urbaniza-} tion

Henan Province should boost the advancement of urbanization, the effective supply of rural digital inclusive finance and the development of innovative and safe products and services, ensuring that financial products are aimed at targeted poverty alleviation. Moreover, for the sake of increasing rural income, it should optimize the allocation pattern of 
digital inclusive finance resources, give full play to the leading role of Zhengzhou as a financial center, strengthen its influence and driving force, enhance the service capabilities of the rural digital inclusive financial industry, and upgrade the supply structure of rural secondary and tertiary industries. In terms of specific operations, based on the advantages of Internet technologies, financial institutions can make full use of cloud computing, artificial intelligence and other technologies to model the information of the rural low-income population and analyze the data and images, thus intelligently customizing personalized menus and recommend suitable products. Additionally, financial institutions can also analyze and supervise the credit status of farmers based on the record of credit information such as blockchain, so that products can be adjusted timely. At the same time, in response of the differentiated demand of farmers, they can also carry out business and product innovation with pertinence in the case of controllable risks.

5.2.4. Reduce the urban-rural income gap and fulfill the demand of rural digital inclusive finance

The economic growth of Henan helps to reduce the income gap between urban and rural areas, promote to alleviate relative poverty in countryside, stimulate the demand for digital inclusive finance, and improve the overall level of local inclusive finance development. The problem of dual economic structure is prominent in Henan, so the government should appropriately adjust the economic structure to meet the financial demand of small farmer households and rural enterprises, and formulate more policies for "supporting agriculture" and "benefiting agriculture "to axe tax burdens for farmers, such as granting farmers subsidies for the interest rate of digital inclusive finance loans and for agricultural machinery, and providing technical training for farmers and employment opportunities for rural surplus labor. In response to the digital inclusive finance demand of rural residents in Henan, financial platforms should take initiative to develop a variety of innovative products and continuously expand the channels of inclusive finance services. Furthermore, with the continuous acceleration of rural population aging in Henan, the cost of social support for the elderly brings much pressure on economic growth. The majority of the elderly are excluded from financial services because of the age issue, so corresponding supporting policies should be introduced to meet their demand for digital inclusive finance.

\section{Conclusion}

By taking the rural income level variable represented by rural per capita disposable income as the explained variable, we took the level of digital inclusive finance as an explanatory variable and conducted regression analysis with panel data of 17 cities in Henan from 2012 to 2018 in order to test the impact of digital inclusive finance on Henan's rural income. In addition, the breadth of coverage, depth of use and degree of digital support service index of digital inclusive finance are used as explanatory variables to prove that they are also beneficial to the rise of rural income.

In terms of Henan as a whole, the development of digital inclusive finance has a positive effect on the level of rural income. This empirical test result is consistent with the expected theoretical analysis. Digital inclusive finance deeply integrates digital technologies and financial services, promotes the convenience of financial services, improves financial services for rural low-income groups, enables farmers to enjoy the same financial services as urban residents and effectively solves the "last mile" problem of inclusive financial services. The growth of rural income has enabled the balanced development of urban and rural areas, ensuring the sustainable development of inclusive finance while effectively alleviating relative poverty in rural areas.

The breadth of coverage, depth of use, and digitalization degree of digital inclusive finance play a positive role in heightening rural income, and they can well root up the problems of geographic exclusion and product exclusion of inclusive finance. First, digital inclusive finance allows residents living in the countryside beyond the coverage of 
financial services to enjoy the identical financial services. Rural low-income residents mostly live in remote areas, and traditional financial institutions do not open up service outlets in remote rural areas out of cost concern, which makes it difficult for rural residents to enjoy the same financial services as urban people, but the birth of digital inclusive finance effectively solves such problems. Users can break through the geographical restrictions of financial services by using mobile terminals such as mobile phones and computers, so that the geographical exclusion of traditional financial services can be mitigated. Secondly, the use of digital inclusive finance actually embraces the use of Internet payment services, credit services, insurance services and currency fund services. In order to alleviate product exclusion, financial institutions should formulate correct strategies, customize products for different groups of people, and enrich traditional financial products. Finally, the degree of digitization also significantly promotes the increase of rural income. Digital inclusive finance institutions take advantage of emerging technologies such as blockchain, big data and cloud computing to lower the operating costs of physical financial institutions, so that more time can be devoted to conduct financial innovation, to give better services to farmers, and to increase rural income.

Author Contributions: All the authors significantly contributed to this study. X.L. and F.Y. proposed the idea. X.L., Z.Z. and F.Y. wrote the manuscript. All authors have read and agreed to the published version of the manuscript.

Funding: This research is supported by the Major Program of the National Social Science Foundation of China (Grant No. 18ZDA089), the National Natural Science Foundation of China (Grant No. 42001235), the Science and Technology Plan Program of Zhoushan (Grant No. 2021C21022) and the National Key Research and Development Program of China (Grant No. 2017YFC0506501).

Institutional Review Board Statement: Not applicable.

Informed Consent Statement: Not applicable.

Conflicts of Interest: The authors declare no conflict of interest.

\section{References}

1. Geda, A.; Shimeles, A.; Zerfu, D. Finance and Poverty in Ethiopia: A Household Level Analysis. Research Paper No. 51, United Nations University, 2006, 45-48.

2. Hannig, A.; Jansen, S. Financial Inclusion and Financial Stability: Current Policy Issues. ADBI Working Pap. 2010, 259.

3. Sarma, M.; Pais, J. Financial Inclusion and Development. J. Int. Dev. 2011, 23, 613-628.

4. Park, C.Y., Rogelio, U. M. Does Financial Inclusion Reduce Poverty and Income Inequality in Developing Asia, London: Palgrave Macmillan, UK, 2016.

5. Jin, D. The Inclusive Finance Have Effects on Alleviating Poverty. Open J. Soc. Sci. 2017, 5, 233-242.

6. Zhu, J. Research on Risk Management and Countermeasures of Inclusive Finance--From the Perspective of Comprehensive Risk Management of Credit Insurance. Financ. Eng. Risk Manage. 2020,3, 147-155.

7. Zheng, F.; Liu, H.; Li, T.; Qiu, P. A study on Inclusive Finance and Enterprise Environmental Investment Single-variable test based on bivariate mechanism. E3S Web Conf. 2021, 235.

8. Zhao, J. Digital Inclusive Finance Is Leading the New Direction of Financial Development. Gansu Financ. 2016, 11, 1. (In Chinese)

9. Dong, Y.; Zhao, X. Responsible Digital Inclusive Finance: Origin, Connotation and Construction. S. China Financ. 2018, 1, 50-56. (In Chinese)

10. Qiu, Z.; Xiang, X. Problems in the Development of Digital Inclusive Finance and the Countermeasures. Financ. Theor. Pract. 2018, 1, 5-9. (In Chinese)

11. Sheng, S. CEIBS Lujiazui Financial Review 2018, Beijing: China Financial Publishing House, China, 2019. (In Chinese)

12. Dittus, P.; Klein, M. On Harnessing the Potential of Financial Inclusion. BIS Working Pap. 2011, 68, 1-18.

13. Munyegera, G. K.; Matsumoto, T. Mobile Money, Remittances, and Household Welfare: Panel Evidence from Rural Uganda. World Dev. 2016, 79, 127-137.

14. Manyika, J.; Lund S.; Singer M. Digital Finance for All: Powering Inclusive Growth in Emerging Economies. America: Mckinsey Global Institute, 2016.

15. Peterson, K. O. Impact of digital finance on financial inclusion and stability. Borsa Istanbul Rev. 2018, 18, 329-340.

16. Li, J.; Wu, Y.; Xiao, J. The impact of digital finance on household consumption: Evidence from China. Econ. Model. 2020, 86, 317326. 
17. Xie, W., Wang, T.; Zhao,X. Does Digital Inclusive Finance Promote Coastal Rural Entrepreneurship? J. Coastal Res. 2020,103, 240-245.

18. Huang, B. A Study on the Effect of Digital Inclusive Finance on the Financial Restraint of Small and Medium-sized Enterprises. E3S Web Conf. 2021, 235.

19. Wang, Y. Threshold Effect of Digital Inclusive Finance on Farmers' Income Growth. Financ. Theor. Pract. 2021, 6, 94-109. (In Chinese)

20. Wang Y. The Effect of Digital Inclusive Finance on the Urban-rural Income Gap: Taking the Yangtze River Delta of China as an Example, J. Shanxi Univ. 2020, 6, 118-126. (In Chinese)

21. Chen, D.; Yao, M. The Empirical Analysis of the Impact of Digital Inclusive Finance on the Rural Income. Shanghai Financ. 2019, 6, 74-77. (In Chinese)

22. Fu, M. Research on the Impact of Rural Financial Development on Farmers' Income Growth in Shaanxi Province, Qinghai University, China, 2020.

23. Liang, S.; Liu, P. Digital Inclusive Finance and the Income Gap Between Urban and Rural Areas. J. Cap. Univ. Econ. Bus. 2019,21, 33-41.

24. Xia, Y. Research on the Impact of China's Digital Inclusive Financial Development on Narrowing the Urban-Rural Income Gap, Yunnan University of Finance and Economics, China, 2018.

25. Xiao, Y. Empirical Research on Poverty Reduction Effects of Digital Inclusive Finance. J. Financ. Perspect. 2020, 8, 48-57. (In Chinese)

26. Luo, H.; Luo, J. Research on the Influences of Inclusive Finance on Rural Poverty Alleviation from a Multidimensional Perspective. Contemp. Econ. Manage. 2019, 41, 80-88. (In Chinese)

27. Wang, Y.; Wen, T. Research on Economic Growth Effect and Heterogeneity of Digital Finance. Mod. Econ. Res. 2020, 11, 56-69. (In Chinese)

28. Xu, Z.; Zhang, L.; Liu, Y. Does the Development of Digital Inclusive Finance Enhance Regional Innovation Capability? Financ. Econ. 2020, 11, 17-28. (In Chinese)

29. Zhao, Y.; Luo, E.; Li, J. The Impacts of the Investment in the Integrated Agricultural Development Projects on Rural Household Income: An Analysis Based on China's Provincial Panel Data, Chin. Rural Econ. 2019, 5, 22-37. (In Chinese)

30. Mandira, S.; Jesim, P. Financial Inclusion and Development. J. Int. Dev. 2011, 7, 613-628.

31. Diniz, E.; Birochi, R.; Pozzebon, M. Triggers and Barriers to Financial Inclusion: The Use of ICT-based Branchless Banking in an Amazon County. Electron. Commer. R. A. 2012, 11, 484-494.

32. Hassan, M.S.; Mahmood, H.; Saeed, M.I.; Alkhateeb, T.T.Y.; Arshed, N.; Mahmoud, D.H.I. Investment Portfolio, Democratic Accountability, Poverty and Income Inequality Nexus in Pakistan: A Way to Social Sustainability. Sustainability 2021, $13,6411$.

33. Świecka, B.; Terefenko, P.; Wiśniewski, T.; Xiao, J. Consumer Financial Knowledge and Cashless Payment Behavior for Sustainable Development in Poland. Sustainability 2021, 13, 6401.

34. Guo, Y.; Zhang, L.; Wang, X. The Economic Effect of Rural Digital Inclusive Finance and Its Influence Factors - Based on Countylevel's Survey Data. J. Shandong Univ. 2020, 11, 122-132.

35. Aizenman, J. On the hidden links between financial and trade opening. J. Int. Money Financ. 2008, 27, 372-386.

36. Maican, S.Ș.; Muntean, A.C.; Paștiu, C.A.; Stępień, S.; Polcyn, J.; Dobra, I.B.; Dârja, M.; Moisă, C.O. Motivational Factors, Job Satisfaction, and Economic Performance in Romanian Small Farms. Sustainability 2021, 13, 5832.

37. Chakravarty, S.; Pal, R. Financial Inclusion in India: An Axiomatic Approach. J. Policy Model. 2013, 35, 813-837.

38. Appleyard, L. Community Development Finance Institutions (CDFIs): Geographies of Financial Inclusion in the US and UK. Geo forum 2011, 42, 250-258.

39. Yu, N.; Wang, Y. Can Digital Inclusive Finance Narrow the Chinese Urban-Rural Income Gap? The Perspective of the Regional Urban-Rural Income Structure. Sustainability 2021, 13, 6427.

40. Wu, S. Risk Issues, Regulatory Challenges and Development Proposals for Digital Inclusive Finance. J. Tech. Econ. Manage. 2019, 1, 66-69.

41. He, H. The Development Dilemma and Innovation Approach of Digital Finance. Gansu Soc. Sci. 2019, 1, 166-171. (In Chinese)

42. Zhang, L. Digital Inclusive Finance, County Industrial Upgrading with Farmers' Income Growth. Res. on Financ. Econ. Iss. 2021, 6, 51-59. (In Chinese) 